\title{
Application of WeChat Assisted Instruction in Photoshop in Higher Vocational Colleges
}

\author{
Xiang Yang \\ Hubei three gorges polytechnic, hubei yichang 443000
}

Keywords: Higher Vocational Colleges; Photoshop Teaching; WeChat; Application Measures

\begin{abstract}
WeChat, the product of the continuous development of modern communication technology, has been widely used in people's daily life and work, and has had an extremely important impact on the development of society. The combination of WeChat and Photoshop course teaching in higher vocational colleges is a scientific means to improve teaching efficiency, so that the teachers should apply WeChat reasonably in their teaching process. Starting from the present situation of Photoshop course teaching in higher vocational colleges, this paper expounds the meaning, characteristics and advantages of the assisted instruction of WeChat, and then analyzes the problems existing in the Photoshop teaching in higher vocational education. Finally, on the basis of the above, the application measures of WeChat assisted instruction in the Photoshop course of higher vocational colleges are discussed in detail, and some points for attention are proposed, hoping to provide some reference for the research of related content in the future.
\end{abstract}

\section{Introduction}

In recent years, the state has gradually attached the importance of and has increased the investment in the vocational education, therefore the vocational education has been significantly improved compared with the past. As an important part of vocational education, higher vocational education has been significantly improved accordingly. With the improvement of overall education quality, Photoshop teaching, one of the organic components of higher vocational education, its quality has also been greatly improved, but some problems still exist in the actual teaching. For example, the change of teaching concept is not timely, the reform of teaching mode is not complete, and the level of teachers' quality is not high, all of which have seriously affected the further improvement of teaching efficiency of Photoshop. Therefore, Photoshop teaching calls for more scientific and reasonable means.

\section{The Basic Content of WeChat and its Advantages in Teaching}

WeChat is a free timely-communication-offered app for smart terminals launched by Tencent on January $21^{\text {st }} 2011$, providing users with text, pictures, videos and language services and supporting group chat and other services at the same time. On August $8^{\text {th }} 2012$, the WeChat Official Account Platform was launched where a WeChat subscriber subscription service was supplied specifically for group users such as the media, corporates, and we-media ${ }^{[2]}$. People have been in favor of the WeChat since the launch of it through which to achieve communication with others, breaking through the time and space constraints to make a higher level of communication possible.

The application of WeChat in teaching has the advantages and functions that the traditional teaching tools cannot compare, which is concentrated in the following aspects: (1) Free use: Application of WeChat in teaching need not consider too much technical costs and operating costs, because users can use it to receive and push messages after registration on the developed software. (2) Simple operation: Only after slight exploration of the WeChat can people grasp the use of it, not difficult for higher vocational students. (3) Wide coverage: WeChat has a very large student user group, and vocational students occupy a large part of it. (4) Various forms: The application of WeChat in teaching can increase the interest of teaching and is a breakthrough of the traditional teaching mode. (5) Resource sharing: Through the functions of QR code and push, all kinds of 
consultation on the Internet can be directly connected to, which highlights the pertinence, integrity and validity of the information ${ }^{[3]}$. (6) Interactive aspects: With the help of WeChat, the interaction of teaching can be realized more conveniently and the enthusiasm of students can be enhanced.

\section{Problems in Photoshop Teaching in Higher Vocational Colleges}

In the teaching of Photoshop in higher vocational colleges, the teaching concept of most teachers has been changed, hence the modern teaching concept has been gradually established, and has been applied well in teaching practice; however, in the actual teaching process, some teachers deeply influenced by traditional teaching concept still exist, resulting that teaching efficiency has been unable to be effectively improved. For example, some teachers take themselves as the center of teaching, but ignore the subjectivity of students when explaining the function of Photoshop software, as a result, students can only passively study with learning efficiency not improved.

Photoshop course is an attractive subject which will arouse the students' interest in learning so as to improve the efficiency of teaching if the teaching method is applied scientifically and reasonably. However, looking at the current situation of Photoshop teaching in higher vocational colleges in the new stage, single teaching method is applied during the teaching, so that the improvement of teaching quality becomes very difficult. For example, the cramming method of teaching limits the students' thinking when explaining the application of Photoshop software, where teachers can choose the cooperative learning method to improve the teaching efficiency.

The higher vocational education has strong applicability in the practice, training applied talents for society, which requires higher vocational education should pay attention to the organic combination of theoretical teaching and practical teaching, and improve the application of teaching. During the Photoshop teaching in higher vocational colleges, teachers should attach great importance to strengthen classroom interaction, by which students can learn more actively, and the improvement of teaching efficiency will become easier. However, in the actual teaching process, the lack of classroom interaction seriously affects the improvement of teaching efficiency.

\section{The Application Strategies of WeChat in Photoshop Teaching in Higher Vocational Colleges}

Considering that many problems mentioned above in the course of Photoshop teaching in higher vocational colleges have a great negative impact on the improvement of teaching efficiency, timely and effective measures must be taken. The WeChat assisted instruction in Photoshop teaching should be considered from three aspects -- WeChat group, WeChat official accounts and WeChat friends circle.

In the teaching of Photoshop in higher vocational colleges, WeChat group can be used actively to improve the efficiency of teaching. A large number of teaching practices have proved that the use of WeChat group to carry out teaching has a great help for the Photoshop teaching efficiency. For example, in the course of Photoshop Image Processing, teachers can take class as a unit to set up a WeChat group, to organize students to discuss a topic or give a unified solution to a question through WeChat group. Students can also ask teachers about problems encountered in classroom teaching, online learning and practical operations, either through group or private chat, not only enhancing the interaction between teachers and students, but also realizing more targeted guidance to students having doubts in practical operation ${ }^{[4]}$. In the limited time of classroom teaching, many usage of Photoshop tools cannot be taught to students one by one. Through the class WeChat group, teachers can consciously add a certain amount of extracurricular learning content, and spent spare time to discuss and communicate with students, both stimulating the initiative and enthusiasm of students, and deepening, supplementing and extending the classroom teaching.

WeChat official account platform is a concrete embodiment of WeChat's powerful function. With the help of it, the efficiency of Photoshop teaching can be effectively improved. In teaching practice, teachers can make full use of WeChat platform to push the learning content on the official account platform, contributing to the preview of the course. The content can be published in a variety of forms, such as texts, pictures, videos, etc. At the same time, the key or difficult parts of the teaching 
can also be explained by teachers on the public platform, so that students can understand them in advance, and make a good preparation for the coming new lessons. During the study through WeChat public platform, students can make use of the strong interactive characteristics of WeChat, to post comments after the articles, thus to improve the interactive learning, and teachers can timely view the interaction of students, then to make the corresponding guidance. The public platform of WeChat assisted teaching reflects the following three characteristics. First, the timeliness of learning is ensured, so that students timely preview the content to be learned and practice what they have learned through reading the contents on the public platform; Second, the pertinence of teaching is achieved, because the content of public platform is usually the core and key parts of teaching; Third, the continuity of learning is realized. The teaching courseware and teaching auxiliary materials can be kept permanently, which is convenient for students to consult at any time and is beneficial to the renewal of knowledge ${ }^{[5]}$.

The friends circle is another form in WeChat with strong interaction and communication. In the teaching process of Photoshop course in higher vocational colleges, teachers can make full use of WeChat friends circle to conduct teaching to give play to the advantages and functions of it. In general, the WeChat friends circle is applied mainly to share the teaching results in Photoshop teaching. As an important part of higher vocational education, Photoshop teaching should actively display the teaching results, to share with more people, making more people understand higher vocational teaching, and then changing the wrong understanding of higher vocational teaching in society ${ }^{[6]}$. WeChat friends circle is precisely the best way to show yourself, thus some good teaching works in Photoshop teaching can be shown in the friends circle, in addition, students can also send their works to their friends circles through the all-round display in the form of pictures or videos, to get more opinions and suggestions, so as to better implement the teaching adjustment and improve the teaching quality.

Although the application of WeChat in Photoshop teaching in higher vocational colleges can help improve the quality of teaching, the following issues should be taken into consideration. First, classroom teaching should be paid much more attention to, avoiding excessive dependence on WeChat. In other words, the degree of WeChat usage should be well grasped, not to use WeChat teaching all the time. Second, the guidance to prevent the use of mobile phones in class should be strengthened. When teaching Photoshop in higher vocational colleges, teachers should guide students to put more WeChat learning after class so as to prevent students from using mobile phones to do some other things in class. Third, the content construction should be enhanced to avoid outdated contents. For the content on the WeChat public platform, teachers should keep pace with the times and update regularly to avoid the outdated contents having no value and significance on teaching.

\section{Conclusion}

In a word, the teaching of Photoshop is a very important part in higher vocational colleges, and the quality of it will have a very important influence on the study and development of students. The application of WeChat to the Photoshop teaching is a scientific means to improve the teaching efficiency of Photoshop and it should be used reasonably in the Photoshop teaching.

\section{References}

[1] Fan Renqiu. Research on the Application of WeChat in Network Aided Teaching of PHOTOSHOP Graphics and Image Processing[J]. Course Education Research, 2017,12(4):203-204.

[2] Zhang Na. The Application of WeChat Aided Teaching in Photoshop in Higher Vocational Colleges[J]. Computer Knowledge and Technology, 2017,13(34):122-123.

[3] Dong Yan. Analysis of the Application of WeChat Platform in Photoshop Teaching in Secondary Vocational Schools[J]. Modern Vocational Education, 2016,45(21):140-141.

[4] Meng Zhiqiang. Research on the Application of WeChat in Aided Teaching in Higher Vocational 
Colleges[J]. Ability and Wisdom, 2016,36(17):217-219.

[5] Chang Yonghu. The Application of WeChat Official Accounts in the Photoshop Image Processing in Colleges and Universities[J]. The Guide of Science and Education Journal, 2016,10(9z):103-104.

[6] Liu Xiaojuan. The Assistant of WeChat Platform in Photoshop Teaching[J]. Education Science, 2016,24(11):00095-00095. 